\title{
Pengaruh Implementasi Peran Guru Bimbingan Konseling Dan Intensitas Mengikuti Kegiatan Osis Terhadap Kedisiplinan Mentaati Tata Tertib Sekolah Pada Siswa SMK Negeri Campalagian Kabupaten Polman Tahun Pelajaran 2019/2020
}

\author{
Muji Rahayu \\ Institut Agama Islam DDI Polewali Mandar \\ Jl. Gatot Soebroto Kelurahan Madatte Kecamatan Polewali Kab. Polewali Mandar
}

\begin{abstract}
ABSTRAK
Penelitian ini bertujuan untuk mengetahui pengaruh implementasi peran guru bimbingan konseling dan intensitas mengikuti kegiatan OSIS terhadap kedisiplinan mentaati tata tertib sekolah pada siswa SMK Negeri Campalagian Kabupaten Polman tahun ajaran 2019/2020. Jenis penelitian ini adalah penelitian korelasi sebab akibat dengan pendekatan penelitian kuantitatif. Populasi dalam penelitian ini adalah semua siswa SMK Negeri Campalagian Kabupaten Polman berjumlah 70 siswa. Jumlah sampel yang diambil sebanyak 40 orang yang diambil dengan cara sampel kombinasi (combined sampling), yaitu "Quota purposive area proportional random sampling".

Hasil penelitian menunjukkan bahwa ada hubungan yang signifikan antara implemenasi peran guru BK dan intensitas mengikuti kegiatan OSIS terhadap kedisiplinan mentaati tata tertib sekolah. Ada pengaruh implemenasi peran guru BK dan intensitas mengikuti kegiatan OSIS terhadap kedisiplinan mentaati tata tertib sekolah pada siswa SMK Negeri 1 Polewali Kabupaten Polman Tahun Pelajaran 2019/2020. Hal ini dibuktikan dari harga Freg $=6,743$, dimana Fhitung $>$ Ftabel $=$ 6,743 $>3,26$ atau 6,743 > 4,38, sehingga Ha diterima. Variabel implementasi peran guru Bimbingan Konseling memberikan sumbangan relatif (SR\%X1) sebesar $47,03 \%$ dan sumbangan efektif (SE\%X1) sebesar 12,56\%. Variabel intensitas mengikuti kegiatan OSIS memberikan sumbangan relatif (SR\%X2) sebesar 52,97\% dan sumbangan efektif (SE\%X2) sebesar 14,15\%. Sehingga intensitas mengikuti kegiatan OSIS memiliki pengaruh yang lebih dominan terhadap kedisiplinan mentaati tata tertib sekolah.
\end{abstract}

Kata Kunci: Implementasi Peran Guru Bimbingan Konseling, Intensitas Mengikuti Kegiatan OSIS dan kedisiplinan mentaati tata tertib sekolah

\section{PENDAHULUAN}

\section{A. Latar Belakang}

Perkembangan pendidikan menengah tidak dapat lepas dari peran Organisasi Siswa Intra Sekolah (OSIS) di sekolah sebagai pembinaan siswa. OSIS merupakan salah satu wadah yang sangat penting bagi anak didik, karena didalam pembinaan siswa diajarkan berbagai ketrampilan dan kedisiplinan. Pemanfaatan OSIS sebagai wadah dalam pembinaan siswa ini salah satu wujud kegiatannya adalah menyelenggarakan upacara bendera, yang dapat melatih dan menanamkan kedisiplinan pada siswa. Disiplin akan membantu siswa untuk menjadi matang pribadinya dan 
mengembangkannya dari ketergantungan menuju ketidak tergantungan, sehingga siswa mampu berdiri sendiri atas tanggung jawab sendiri.

Adanya disiplin siswa berarti siswa tunduk pada peraturan-peraturan yang ada dalam tata tertib sekolah dengan senang hati. Perlu dipahami bahwa OSIS akan berfungsi efektif sebagai salah satu wadah siswa, apabila didukung oleh partisipasi yang tinggi dari para peserta didik.

Manfaat dan perlunya kepatuhan terhadap peraturan bagi diri sendiri ialah adanya ketenangan batin dan ketentraman hati, tidak merasa khawatir karena dikejar-kejar oleh perasaan bersalah. Kepatuhan terhadap peraturan akan melatih hidup teratur dan berdisiplin yang akhirnya dapat membawa untuk mencapai kebahagiaan.

Membiasakan diri hidup tertib dan teratur dalam kehidupan sehari-hari harus dilatih sejak dini. Apabila hidup tertib dan teratur sudah mendarah daging dalam diri sendiri, maka apabila melihat ketidaktertiban dan ketidakteraturan akan tergeraklah hati untuk menertibkan dan membuatnya teratur.

Disiplin merupakan kunci sukses, karena dengan berdisiplin akan menumbuhkan sifat yang teguh dalam memegang prinsip tekun dalam berusaha mundur dalam kebenaran dan rela berkorban dan serta jauh dari sifat putus asa. Oleh karena itu disiplin sangat, penting dan besar pengaruhnya dalam kehidupan pribadi, bermasyarakat, berbangsa dan bernegara.

Tidak dapat disangkal bahwa orang-orang, yang berhasil mencapai sukses dalam hidupnya adalah orang-orang yang hidup berhasil mencapai disiplin, memanfaatkan waktunya. Disiplin tidak akan datang dengan sendirinya, akan tetapi melalui latihan yang ketat dalam kehidupan pribadinya.

Salah satu usaha menanamkan dan menumbuhkan sikap disiplin pada manusia Indonesia terutama pada generasi muda diantaranya adalah melalui pendidikan, baik yang diberikan dalam lingkungan keluarga, pendidikan formal di sekolah maupun pendidikan dalam lingkungan masyarakat. Jadi pendidikan berlangsung seumur hidup dan bertujuan untuk meningkatkan kecerdasan sehingga akan lebih mendorong tercapainya peningkatan kesejahteraan rakyat demi tercapainya peningkatan demi tercapainya kemanusiaan yang adil dan beradab dan keadilan sosial bagi seluruh rakyat Indonesia. Sebagaimana tercantum dalam Undang-Undang No. 20 Tahun 2003 pasal 3, telah digariskan bahwa:

Pendidikan Nasional bertujuan mencerdaskan kehidupan bangsa dan mengembangkan manusia Indonesia seutuhnya, yaitu manusia yang beriman dan bertaqwa terhadap Tuhan Yang Maha Esa dan berbudi pekerti luhur, memiliki pengetahuan dan ketrampilan, kesehatan jasmani dan rohani, kepribadian yang mantap dan mandiri serta rasa tanggung jawab kemasyarakat dan kebangsaan (RI, 2003:30).

Di Indonesia yang berdasarkan Pancasila, di dalam dunia pendidikan formal untuk membina sikap dan moral yang dapat menumbuhkan sifat disiplin peserta didik dapat ditempuh antara lain melalui mata pelajaran Bimbingan Konseling (BK). Melalui mata pelajaran Bimbingan Konseling diharapkan para peserta didik dapat meningkatkan pengetahuan dan mengembangkan kemampuan, memahami, menghayati, dan meyakini nilai-nilai Pancasila sebagai pedoman berperilaku dalam kehidupan bermasyarakat, berbangsa dan bernegara sehingga menjadi warga negara yang bertanggung jawab dan dapat diandalkan serta memberi bekal kemampuan untuk belajar lebih lanjut. 
Hakekat manusia menurut sifat kodrat monodualisme sebagai makhluk individu dan makhluk sosial. Sebagai makhluk individu terdiri atas jasmani dan rohani yang tidak dapat dipisah-pisahkan. Bersatunya jasmani dan rohani membentuk ciri-ciri tersendiri diantaranya mempunyai cipta, rasa dan karsa. Sifat individu manusia mengarah kepada kepentingan pribadinya. Sebagai makhluk sosial, manusia merupakan anggota dari suatu kelompok. Pola kehidupan manusia dalam kelompok pada umumnya akan mempengaruhi sikap sosial manusia, sehingga manusia akan berusaha untuk menonjolkan diri diantara manusia-manusia yang lain, dengan demikian sangat memungkinkan terciptanya interaksi antara yang satu dengan yang lainnya.

Sejak anak-anak manusia mulai mengenal atau belajar melalui norma, adat- istiadat, dan lingkungan sebagai pedoman tingkah laku untuk kehidupan selanjutnya. Pada waktu menginjak remaja usia remaja terjadilah perubahan dalam dirinya baik fisik, psikologis maupun sosialnya. Mereka ingin melepas saja sifat kekanak-kanakannya, tetapi mereka belum dapat bertingkah laku secara dewasa. Pada masa remaja akhir mulai menyadari bahwa manusia akan hidup sendiri, tanpa bantuan dari orang lain. Peranan sikap sosial ini memegang peranan yang sangat penting, baik dalam kehidupan bermasyarakat maupun dalam kehidupan berkelompok.

Kedisiplinan siswa pada dasarnya dipengaruhi oleh banyak faktor yang saling terkait baik yang berasal dari dalam maupun dari luar. Pada hakekatnya tidak ada faktor tunggal yang berdiri sendiri yang secara otomatis menentukan kedisiplinan siswa. Faktor-faktor tersebut antara lain faktor kesadaran dari individu, pola asuh dari orang tua, bimbingan guru konseling, sanksi yang diterapkan, intensitas kegiatan di sekolah, lingkungan pergaulan siswa, lingkungan tempat tinggal siswa, lingkungan sosial siswa, dan lain sebagainya.

Berdasarkan uraian latar belakang dan identifikasi permasalahan di atas, maka penulis tertarik untuk mengadakan penelitian mengenai pengaruh implementasi peran guru bimbingan konseling dan intensitas mengikuti kegiatan OSIS terhadap kedisiplinan mentaati tata tertib sekolah pada siswa SMK Negeri Campalagian Kabupaten Polman tahun pelajaran 2019/2020.

Permasalahan yang berkaitan dengan judul di atas sangat luas, maka dalam hal ini penulis membatasi ruang lingkup dan fokus masalah yang diteliti. Obyek penelitian adalah 1) Implementasi peran guru bimbingan konseling pada siswa, 2) Intensitas siswa mengikuti kegiatan OSIS, dan 3) Kedisiplinan siswa mentaati tata tertib sekolah. Subyek penelitian adalah siswa SMK Negeri Campalagian Kabupaten Polman tahun ajaran 2019/2020.

\section{B. Rumusan Masalah}

Berdasarkan latar belakang masalah tersebut di atas maka dapat dirumuskan suatu permasalahan sebagai berikut: "Adakah pengaruh positif yang signifikan dari implementasi peran guru bimbingan konseling dan intensitas mengikuti kegiatan OSIS terhadap kedisiplinan mentaati tata tertib sekolah pada siswa SMK Negeri Campalagian Kabupaten Polman tahun ajaran 2019/2020?"

\section{Hipotesis Penelitian}

Hipotesis dalam penelitian ini adalah: "Ada pengaruh positif yang signifikan dari implementasi peran guru bimbingan konseling dan intensitas mengikuti kegiatan OSIS terhadap 
kedisiplinan mentaati tata tertib pada siswa SMK Negeri Campalagian Kabupaten Polman tahun ajaran 2019/2020".

\section{Tujuan Penelitian}

1. Untuk mengetahui implementasi peran guru bimbingan konseling pada siswa SMK Negeri Campalagian Kabupaten Polman tahun ajaran 2019/2020.

2. Untuk mengetahui intensitas mengikuti kegiatan OSIS pada siswa SMK Negeri Campalagian Kabupaten Polman tahun ajaran 2019/2020.

3. Untuk mengetahui kedisiplinan mentaati tata tertib pada siswa SMK Negeri Campalagian Kabupaten Polman tahun ajaran 2019/2020.

4. Untuk mengetahui ada tidaknya pengaruh implementasi peran guru bimbingan konseling dan intensitas mengikuti kegiatan OSIS terhadap kedisiplinan mentaati tata tertib sekolah pada siswa SMK Negeri Campalagian Kabupaten Polman tahun ajaran 2019/2020.

\section{METODE PENELITIAN}

Jenis penelitian yang digunakan dalam penelitian ini adalah penelitian korelasi sebab akibat dengan pendekatan penelitian kuantitatif. Penelitian ini dilaksanakan di SMK Negeri Campalagian Kabupaten Polman selama kurang lebih lima bulan, yaitu sejak bulan Juni sampai dengan bulan Oktober 2019. Populasi dalam penelitian ini adalah semua siswa SMK Negeri Campalagian Kabupaten Polman berjumlah 70 siswa. Jumlah sampel yang diambil sebanyak 40 orang yang diambil dengan cara sampel kombinasi (combined sampling), yaitu "Quota purposive area proportional random sampling".

Variabel-variabel dalam penelitian ini mencakup variabel bebas pertama (X1) yaitu implementasi peran guru bimbingan konseling, variabel bebas kedua (X2) yaitu intensitas siswa mengikuti kegiatan OSIS, dan variabel terikat (Y) yaitu kedisiplinan siswa mentaati tata tertib sekolah.

Untuk mendapatkan data-data atau keterangan yang diperlukan dalam penelitian ini, penulis menggunakan beberapa metode pengumpulan data yang relevan untuk memecahkan masalah tersebut, yaitu metode angket (kuesioner), observasi dan wawancara. Metode angket digunakan untuk mengumpulkan data implementasi peran guru bimbingan konseling dan intensitas mengikuti kegiatan OSIS (Organisasi Siswa Intra Sekolah) serta data kedisiplinan mentaati tata tertib sekolah pada siswa SMK Negeri Campalagian Kabupaten Polman tahun ajaran 2019/2020. Metode observasi digunakan untuk mengkonfirmasi data, terutama data mengenai implementasi peran guru bimbingan konseling, intensitas mengikuti kegiatan OSIS, maupun data kedisiplinan mentaati tata tertib sekolah. Metode wawancara digunakan untuk memperkuat dan memperjelas data yang diperoleh melalui angket.

Data-data yang diperoleh dari observasi, wawancara, dan kuesioner (angket) yang diberikan kepada responden untuk dijawab serta dokumentasi disusun secara kelompok dan diorganisasikan sesuai dengan rumusan masalah, kemudian dilakukan analisis statistik deskriptif dan analisis statistik inferensial untuk uji hiotesis. 


\section{HASIL PENELITIAN DAN PEMBAHASAN}

\section{A. Data Hasil Penelitian}

Gabungan data yang meliputi data implementasi peran guru Bimbingan Konseling (BK), intensitas mengikuti kegiatan OSIS (Organisasi Siswa Intra Sekolah), dan kedisiplinan mentaati tata tertib sekolah pada siswa SMK Negeri Campalagian Kabupaten Polman Tahun Pelajaran 2019/2020. Data gabungan tersebut dipaparkan dalam tabel 1 berikut.

Tabel 1.

Data Skor Implementasi Peran Guru BK (X1), Intensitas mengikuti kegiatan OSIS (X2), dan Kedisiplinan Mentaati Tata Tertib Sekolah (Y)

\begin{tabular}{|c|c|c|c|}
\hline No & X1 & X2 & Y \\
\hline 1 & 69 & 64 & 77 \\
2 & 72 & 60 & 72 \\
3 & 69 & 60 & 67 \\
4 & 61 & 61 & 69 \\
5 & 48 & 39 & 57 \\
6 & 67 & 46 & 71 \\
7 & 69 & 40 & 72 \\
8 & 68 & 41 & 65 \\
9 & 68 & 46 & 78 \\
10 & 71 & 45 & 65 \\
11 & 77 & 46 & 72 \\
12 & 72 & 40 & 74 \\
13 & 66 & 43 & 63 \\
14 & 78 & 68 & 74 \\
15 & 55 & 47 & 61 \\
16 & 73 & 42 & 61 \\
17 & 79 & 65 & 74 \\
18 & 78 & 65 & 70 \\
19 & 58 & 48 & 58 \\
20 & 74 & 50 & 71 \\
21 & 74 & 51 & 65 \\
22 & 81 & 70 & 75 \\
\hline
\end{tabular}

Penelitian ini terdiri dari tiga variabel, yaitu implementasi peran guru BK (X1), intensitas siswa mengikuti kegiatan OSIS (X2), dan kedisiplinan siswa mentaati tata tertib sekolah (Y). Data ketiga variabel tersebut sebelum dianalisis, terlebih dahulu dilakukan uji persyaratan, yaitu uji normalitas. Uji ini dilakukan karena untuk analisis regresi mensyaratkan hal tersebut, sehingga hasil dari analisisnya dapat dipertanggung jawabkan. Masing-masing uji yang dimaksud dipapakan dalam uraian berikut ini:

\section{Uji Normalitas}


Uji normalitas dilakukan untuk mengetahui apakah data implementasi peran guru BK (X1), intensitas mengikuti kegiatan OSIS (X2), dan kedisiplinan mentaati tata tertib sekolah (Y) yang diperoleh dalam penelitian ini berasal dari distribusi yang normal atau tidak, karena jika data tidak normal maka analisis data tidak dapat dilakukan.

Tabel 2.

Hasil Perhitungan Uji Normalitas Data Skor Implementasi

Peran Guru Bimbingan Konseling (BK)

\begin{tabular}{l|l|l|l|l|l} 
No. & $\mathrm{Xi}$ & $\mathrm{Zi}$ & $\mathrm{F}(\mathrm{Zi})$ & $\mathrm{S}(\mathrm{Zi})$ & $\mathrm{F}(\mathrm{Zi})-\mathrm{S}(\mathrm{Zi})$ \\
\end{tabular}




\begin{tabular}{|c|c|c|c|c|c|}
\hline 1 & 48 & $-2,51$ & 0,0060 & 0,0250 & 0,0190 \\
\hline 2 & 52 & $-2,02$ & 0,0217 & 0,0500 & 0,0283 \\
\hline 3 & 55 & $-1,65$ & 0,0495 & 0,1000 & 0,0505 \\
\hline 4 & 55 & $-1,65$ & 0,0495 & 0,1000 & 0,0505 \\
\hline 5 & 56 & $-1,52$ & 0,0643 & 0,1250 & 0,0607 \\
\hline 6 & 58 & $-1,27$ & 0,1020 & 0,1500 & 0,0480 \\
\hline 7 & 60 & $-1,03$ & 0,1515 & 0,1750 & 0,0235 \\
\hline 8 & 61 & $-0,90$ & 0,1841 & 0,2000 & 0,0159 \\
\hline 9 & 62 & $-0,78$ & 0,2177 & 0,2500 & 0,0323 \\
\hline 10 & 62 & $-0,78$ & 0,2177 & 0,2500 & 0,0323 \\
\hline 11 & 65 & $-0,41$ & 0,3409 & 0,3000 & 0,0409 \\
\hline 12 & 65 & $-0,41$ & 0,3409 & 0,3000 & 0,0409 \\
\hline 13 & 66 & $-0,29$ & 0,3859 & 0,3250 & 0,0609 \\
\hline 14 & 67 & $-0,16$ & 0,4364 & 0,3500 & 0,0864 \\
\hline 15 & 68 & $-0,04$ & 0,4840 & 0,4500 & 0,0340 \\
\hline 16 & 68 & $-0,04$ & 0,4840 & 0,4500 & 0,0340 \\
\hline 17 & 68 & $-0,04$ & 0,4840 & 0,4500 & 0,0340 \\
\hline 18 & 68 & $-0,04$ & 0,4840 & 0,4500 & 0,0340 \\
\hline 19 & 69 & 0,08 & 0,5319 & 0,5500 & 0,0181 \\
\hline 20 & 69 & 0,08 & 0,5319 & 0,5500 & 0,0181 \\
\hline 21 & 69 & 0,08 & 0,5319 & 0,5500 & 0,0181 \\
\hline 22 & 69 & 0,08 & 0,5319 & 0,5500 & 0,0181 \\
\hline 23 & 70 & 0,21 & 0,5832 & 0,5750 & 0,0082 \\
\hline 24 & 71 & 0,33 & 0,6293 & 0,6000 & 0,0293 \\
\hline 25 & 72 & 0,45 & 0,6736 & 0,6750 & 0,0014 \\
\hline 26 & 72 & 0,45 & 0,6736 & 0,6750 & 0,0014 \\
\hline 27 & 72 & 0,45 & 0,6736 & 0,6750 & 0,0014 \\
\hline 28 & 73 & 0,58 & 0,7190 & 0,7250 & 0,0060 \\
\hline 29 & 73 & 0,58 & 0,7190 & 0,7250 & 0,0060 \\
\hline 30 & 74 & 0,70 & 0,7580 & 0,8000 & 0,0420 \\
\hline 31 & 74 & 0,70 & 0,7580 & 0,8000 & 0,0420 \\
\hline 32 & 74 & 0,70 & 0,7580 & 0,8000 & 0,0420 \\
\hline 33 & 77 & 1,07 & 0,8577 & 0,8500 & 0,0077 \\
\hline 34 & 77 & 1,07 & 0,8577 & 0,8500 & 0,0077 \\
\hline 35 & 78 & 1,19 & 0,8830 & 0,9000 & 0,0170 \\
\hline 36 & 78 & 1,19 & 0,8830 & 0,9000 & 0,0170 \\
\hline 37 & 79 & 1,32 & 0,9066 & 0,9650 & 0,0684 \\
\hline 38 & 79 & 1,32 & 0,9066 & 0,9650 & 0,0684 \\
\hline 39 & 79 & 1,32 & 0,9066 & 0,9650 & 0,0684 \\
\hline 40 & 81 & 1,56 & 0,9406 & 1,0000 & 0,0594 \\
\hline
\end{tabular}

Berdasarkan tabel 2 diketahui bahwa kolom $\mathrm{F}(\mathrm{Zi})$ - $\mathrm{S}(\mathrm{Zi})$ hasil terbesarnya, terdapat data kolom terakhir dari $(0,05)$ didapat Ltabel 0,1401 , Lhitung $\alpha(0,01)$ didapat Ltabel $=0,1743$ sedangkan pada taraf nyata $\alpha$ tabel, yaitu Lhitung $=0,0864$, kemudian, dikonsultasikan dengan tabel ternyata untuk $\mathrm{N}=40$ pada taraf nyata $<$ Ltabel yaitu $0,0864<0,1743$ dan $0,0864<0,1401$. Jadi data implementasi peran guru BK pada siswa SMK Negeri 1 Polewali Kabupaten Polman adalah normal. 
Tabel 3.

Hasil Perhitungan Uji Normalitas Data Skor Intensitas mengikuti kegiatan OSIS

\begin{tabular}{|c|c|c|c|c|c|}
\hline No. & $\mathbf{X i}$ & $\mathbf{Z i}$ & $\mathbf{F}(\mathrm{Zi})$ & $\mathbf{S}(\mathrm{Zi})$ & $\mathbf{F}(Z \mathbf{i})-\mathbf{S}(\mathbf{Z i})$ \\
\hline 1 & 39 & $-1,42$ & 0,0778 & 0,0250 & 0,0528 \\
\hline 2 & 40 & $-1,31$ & 0,0951 & 0,1000 & 0,0049 \\
\hline 3 & 40 & $-1,31$ & 0,0951 & 0,1000 & 0,0049 \\
\hline 4 & 40 & $-1,31$ & 0,0951 & 0,1000 & 0,0049 \\
\hline 5 & 41 & $-1,20$ & 0,1151 & 0,1500 & 0,0349 \\
\hline 6 & 41 & $-1,20$ & 0,1151 & 0,1500 & 0,0349 \\
\hline 7 & 42 & $-1,09$ & 0,1379 & 0,1750 & 0,0371 \\
\hline 8 & 43 & $-0,98$ & 0,1635 & 0,2250 & 0,0615 \\
\hline 9 & 43 & $-0,98$ & 0,1635 & 0,2250 & 0,0615 \\
\hline 10 & 45 & $-0,76$ & 0,2236 & 0,2750 & 0,0514 \\
\hline 11 & 45 & $-0,76$ & 0,2236 & 0,2750 & 0,0514 \\
\hline 12 & 46 & $-0,65$ & 0,2558 & 0,3750 & 0,1192 \\
\hline 13 & 46 & $-0,65$ & 0,2558 & 0,3750 & 0,1192 \\
\hline 14 & 46 & $-0,65$ & 0,2558 & 0,3750 & 0,1192 \\
\hline 15 & 46 & $-0,65$ & 0,2558 & 0,3750 & 0,1192 \\
\hline 16 & 47 & $-0,54$ & 0,2946 & 0,4250 & 0,1304 \\
\hline 17 & 47 & $-0,54$ & 0,2946 & 0,4250 & 0,1304 \\
\hline 18 & 48 & $-0,43$ & 0,3336 & 0,4500 & 0,1164 \\
\hline 19 & 50 & $-0,21$ & 0,4168 & 0,5500 & 0,1332 \\
\hline 20 & 50 & $-0,21$ & 0,4168 & 0,5500 & 0,1332 \\
\hline 21 & 50 & $-0,21$ & 0,4168 & 0,5500 & 0,1332 \\
\hline 22 & 50 & $-0,21$ & 0,4168 & 0,5500 & 0,1332 \\
\hline 23 & 51 & $-0,10$ & 0,4602 & 0,5750 & 0,1148 \\
\hline 24 & 53 & 0,12 & 0,5478 & 0,6000 & 0,0522 \\
\hline 25 & 55 & 0,34 & 0,6331 & 0,6250 & 0,0081 \\
\hline 26 & 56 & 0,45 & 0,6736 & 0,6500 & 0,0236 \\
\hline 27 & 58 & 0,67 & 0,7486 & 0,6750 & 0,0736 \\
\hline 28 & 60 & 0,89 & 0,8138 & 0,8000 & 0,0138 \\
\hline 29 & 60 & 0,89 & 0,8138 & 0,7250 & 0,0888 \\
\hline 30 & 60 & 0,89 & 0,8138 & 0,8000 & 0,0138 \\
\hline 31 & 60 & 0,89 & 0,8138 & 0,8000 & 0,0138 \\
\hline 32 & 60 & 0,89 & 0,8138 & 0,8000 & 0,0138 \\
\hline 33 & 61 & 1,00 & 0,8413 & 0,8250 & 0,0163 \\
\hline 34 & 62 & 1,11 & 0,8665 & 0,8500 & 0,0165 \\
\hline 35 & 64 & 1,33 & 0,9082 & 0,8750 & 0,0332 \\
\hline 36 & 65 & 1,44 & 0,9251 & 0,9500 & 0,0249 \\
\hline 37 & 65 & 1,44 & 0,9251 & 0,9500 & 0,0249 \\
\hline 38 & 65 & 1,44 & 0,9251 & 0,9500 & 0,0249 \\
\hline 39 & 68 & 1,77 & 0,9616 & 0,9650 & 0,0134 \\
\hline 40 & 70 & 1,99 & 0,9767 & 1,0000 & 0,0233 \\
\hline
\end{tabular}

Berdasar tabel 3 diketahui bahwa kolom $\mathrm{F}(\mathrm{Zi})$ - S(Zi) hasil terbesarnya terdapat data kolom terakhir dari tabel, diperoleh Lhitung $=0,1332$, Ltabel $\alpha(0,01)=0,1743$, untuk $\mathrm{N}=40$ pada taraf nyata 0,1401 . Dengan demikian Lhitung $<$ Ltabel yaitu $0,1332<0,1743$ dan $0,1332<0,1401$. Oleh 
karena itu penyebaran data intensitas mengikuti kegiatan OSIS pada siswa SMK Negeri 1 Polewali adalah normal.

Tabel 4.

Hasil Perhitungan Uji Normalitas Data Skor Kedisiplinan Mentaati Tata Tertib Sekolah

\begin{tabular}{|c|c|c|c|c|c|}
\hline $\mathbf{N o .}$ & $\mathbf{X i}$ & $\mathbf{Z i}$ & $\mathbf{F}(\mathbf{Z i})$ & $\mathbf{S}(\mathbf{Z i})$ & $\mathbf{F}(\mathbf{Z i}) \mathbf{-} \mathbf{S}(\mathbf{Z i})$ \\
\hline 1 & 50 & $-2,36$ & 0,0091 & 0,0250 & 0,0159 \\
2 & 51 & $-2,23$ & 0,0129 & 0,0500 & 0,0371 \\
3 & 53 & $-1,96$ & 0,0250 & 0,0750 & 0,0500 \\
4 & 54 & $-1,83$ & 0,0336 & 0,1000 & 0,0664 \\
5 & 57 & $-1,43$ & 0,0764 & 0,1250 & 0,0486 \\
6 & 58 & $-1,30$ & 0,0968 & 0,1500 & 0,0532 \\
7 & 61 & $-0,91$ & 0,1814 & 0,2000 & 0,0186 \\
8 & 61 & $-0,91$ & 0,1814 & 0,2000 & 0,0186 \\
9 & 63 & $-0,64$ & 0,2611 & 0,2250 & 0,0361 \\
10 & 65 & $-0,38$ & 0,3520 & 0,3250 & 0,0270 \\
11 & 65 & $-0,38$ & 0,3520 & 0,3250 & 0,0270 \\
12 & 65 & $-0,38$ & 0,3520 & 0,3250 & 0,0270 \\
13 & 65 & $-0,38$ & 0,3520 & 0,3250 & 0,0270 \\
14 & 66 & $-0,25$ & 0,4013 & 0,3750 & 0,0263 \\
15 & 66 & $-0,25$ & 0,4013 & 0,3750 & 0,0263 \\
16 & 67 & $-0,12$ & 0,4522 & 0,4250 & 0,0272 \\
17 & 67 & $-0,12$ & 0,4522 & 0,4250 & 0,0272 \\
18 & 68 & 0,02 & 0,5080 & 0,4500 & 0,0580 \\
19 & 69 & 0,15 & 0,5596 & 0,5000 & 0,0596 \\
20 & 69 & 0,15 & 0,5596 & 0,5000 & 0,0596 \\
21 & 70 & 0,28 & 0,6103 & 0,5500 & 0,0603 \\
22 & 70 & 0,28 & 0,6103 & 0,5500 & 0,0603 \\
23 & 71 & 0,41 & 0,6591 & 0,6250 & 0,0341 \\
24 & 71 & 0,41 & 0,6591 & 0,6250 & 0,0341 \\
25 & 71 & 0,41 & 0,6591 & 0,6250 & 0,0341 \\
26 & 72 & 0,54 & 0,7054 & 0,7250 & 0,0196 \\
27 & 72 & 0,54 & 0,7054 & 0,7250 & 0,0196 \\
28 & 72 & 0,54 & 0,7054 & 0,7250 & 0,0196 \\
29 & 72 & 0,54 & 0,7054 & 0,7250 & 0,0196 \\
30 & 73 & 0,68 & 0,7517 & 0,7500 & 0,0017 \\
31 & 74 & 0,81 & 0,7910 & 0,8250 & 0,0340 \\
32 & 74 & 0,81 & 0,7910 & 0,8250 & 0,0340 \\
33 & 74 & 0,81 & 0,7910 & 0,8250 & 0,0340 \\
34 & 75 & 0,94 & 0,8264 & 0,8750 & 0,0486 \\
35 & 75 & 0,94 & 0,8264 & 0,8750 & 0,0486 \\
36 & 77 & 1,20 & 0,8849 & 0,9500 & 0,0651 \\
37 & 77 & 1,20 & 0,8849 & 0,9500 & 0,0651 \\
38 & 77 & 1,20 & 0,8849 & 0,9500 & 0,0651 \\
39 & 78 & 1,34 & 0,9099 & 0,9650 & 0,0651 \\
40 & 80 & 1,60 & 0,9452 & 1,0000 & 0,0548 \\
\hline
\end{tabular}


Berdasarkan tabel 4 tentang ringkasan hasil uji normalitas data untuk variabel kedisiplinan mentaati tata tertib sekolah diketahui bahwa kolom $\mathrm{F}(\mathrm{Zi})-\mathrm{S}(\mathrm{Zi})$ hasil terbesarnya terdapat data kolom terakhir dari tabel, yaitu Lhitung $=0,0664$, setelah dikonsultasikan dengan tabel ternyata $(0,01)$ didapat Ltabelountuk $\mathrm{N}=40$ pada taraf nyata $=0,1743$ sedangkan $(0,05)$ didapat Ltabel 0,1401. Dengan demikian Lhitung apada taraf nyata $<$ Ltabel yaitu $0,0664<0,1743$ dan 0,0664 < 0,1401. Oleh karena itu dapat disimpulkan bahwa data tentang kedisiplinan mentaati tata tertib sekolah pada siswa SMK Negeri Campalagian Kabupaten Polman Tahun Pelajaran 2019/2020 adalah normal.

\section{Analisis Data dan Pengujian Hipotesis}

Untuk menganalisis data pengaruh implementasi peran guru Bimbingan Konseling (BK) dan intensitas mengikuti kegiatan OSIS (Organisasi Siswa Intra Sekolah) terhadap kedisiplinan mentaati tata tertib sekolah, menggunakan teknik analisis regresi dua prediktor. Langkah-langkahnya diawali dengan tabulasi data kemudian dilanjutkan perhitungan-perhitungan. Adapun penyajian perhitungan analisis regresi dua prediktor sebagaimana tercantum dalam tabel 5 berikut ini.

Tabel 5.

Persiapan Analisis Regresi Dua Prediktor (X1 dan X2) dengan Y

\begin{tabular}{|c|c|c|c|c|c|c|c|c|c|}
\hline No & $\mathbf{X 1}$ & $\mathbf{X 2}$ & $\mathbf{Y}$ & $\mathbf{X 1}^{\mathbf{2}}$ & $\mathbf{X 2}^{\mathbf{2}}$ & $\mathbf{Y}^{\mathbf{2}}$ & $\mathbf{X 1 . Y}$ & $\mathbf{X 2 . Y}$ & $\mathbf{X 1 . X 2}$ \\
\hline 1 & 69 & 64 & 77 & 4761 & 4096 & 5929 & 5313 & 4928 & 4416 \\
2 & 72 & 60 & 72 & 5184 & 3600 & 5184 & 5184 & 4320 & 4320 \\
3 & 69 & 60 & 67 & 4761 & 3600 & 4489 & 4623 & 4020 & 4140 \\
4 & 61 & 61 & 69 & 3721 & 3721 & 4761 & 4209 & 4209 & 3721 \\
5 & 48 & 39 & 57 & 2304 & 1521 & 3249 & 2736 & 2223 & 1872 \\
6 & 67 & 46 & 71 & 4489 & 2116 & 5041 & 4757 & 3266 & 3082 \\
7 & 69 & 40 & 72 & 4761 & 1600 & 5184 & 4968 & 2880 & 2760 \\
8 & 68 & 41 & 65 & 4624 & 1681 & 4225 & 4420 & 2665 & 2788 \\
9 & 68 & 46 & 78 & 4624 & 2116 & 6084 & 5304 & 3588 & 3128 \\
10 & 71 & 45 & 65 & 5041 & 2025 & 4225 & 4615 & 2925 & 3195 \\
11 & 77 & 46 & 72 & 5929 & 2116 & 5184 & 5544 & 3312 & 3542 \\
12 & 72 & 40 & 74 & 5184 & 1600 & 5476 & 5328 & 2960 & 2880 \\
13 & 66 & 43 & 63 & 4356 & 1849 & 3969 & 4158 & 2709 & 2838 \\
14 & 78 & 68 & 74 & 6084 & 4624 & 5476 & 5772 & 5032 & 5304 \\
15 & 55 & 47 & 61 & 3025 & 2209 & 3721 & 3355 & 2867 & 2585 \\
16 & 73 & 42 & 61 & 5329 & 1764 & 3721 & 4453 & 2562 & 3066 \\
17 & 79 & 65 & 74 & 6241 & 4225 & 5476 & 5846 & 4810 & 5135 \\
18 & 78 & 65 & 70 & 6084 & 4225 & 4900 & 5460 & 4550 & 5070 \\
19 & 58 & 48 & 58 & 3364 & 2304 & 3364 & 3364 & 2784 & 2784 \\
20 & 74 & 50 & 71 & 5476 & 2500 & 5041 & 5254 & 3550 & 3700 \\
21 & 74 & 51 & 65 & 5476 & 2601 & 4225 & 4810 & 3315 & 3774 \\
22 & 81 & 70 & 75 & 6561 & 4900 & 5625 & 6075 & 5250 & 5670 \\
23 & 62 & 58 & 70 & 3844 & 3364 & 4900 & 4340 & 4060 & 3596 \\
24 & 70 & 60 & 67 & 4900 & 3600 & 4489 & 4690 & 4020 & 4200 \\
25 & 69 & 45 & 66 & 4761 & 2025 & 4356 & 4554 & 2970 & 3105 \\
26 & 74 & 65 & 72 & 5476 & 4225 & 5184 & 5328 & 4680 & 4810 \\
27 & 68 & 60 & 71 & 4624 & 3600 & 5041 & 4828 & 4260 & 4080 \\
28 & 79 & 55 & 77 & 6241 & 3025 & 5929 & 6083 & 4235 & 4345 \\
29 & 73 & 41 & 65 & 5329 & 1681 & 4225 & 4745 & 2665 & 2993 \\
\hline
\end{tabular}




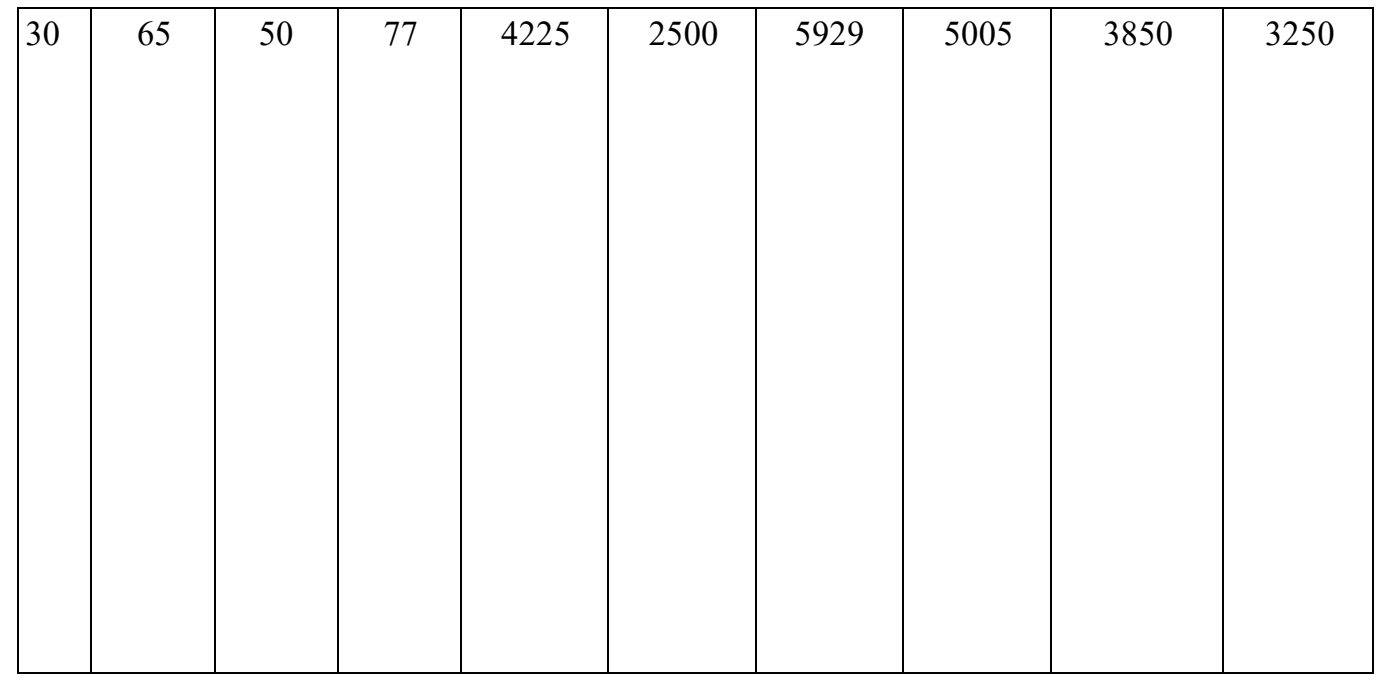

\begin{tabular}{|c|c|c|c|c|c|c|c|c|c|}
\hline 31 & 55 & 62 & 75 & 3025 & 3844 & 5625 & 4125 & 4650 & 3410 \\
\hline 32 & 72 & 60 & 80 & 5184 & 3600 & 6400 & 5760 & 4800 & 4320 \\
\hline 33 & 77 & 56 & 73 & 5929 & 3136 & 5329 & 5621 & 4088 & 4312 \\
\hline 34 & 62 & 40 & 66 & 3844 & 1600 & 4356 & 4092 & 2640 & 2480 \\
\hline 35 & 68 & 46 & 69 & 4624 & 2116 & 4761 & 4692 & 3174 & 3128 \\
\hline 36 & 52 & 47 & 68 & 2704 & 2209 & 4624 & 3536 & 3196 & 2444 \\
\hline 37 & 65 & 53 & 51 & 4225 & 2809 & 2601 & 3315 & 2703 & 3445 \\
\hline 38 & 60 & 50 & 53 & 3600 & 2500 & 2809 & 3180 & 2650 & 3000 \\
\hline 39 & 79 & 50 & 54 & 6241 & 2500 & 2916 & 4266 & 2700 & 3950 \\
\hline 40 & 56 & 43 & 50 & 3136 & 1849 & 2500 & 2800 & 2150 & 2408 \\
\hline \multirow[b]{2}{*}{$\mathrm{N}=40$ C } & 2733 & 2078 & 2715 & 189291 & 111176 & 186523 & 186508 & 142216 & 143046 \\
\hline & $\mathrm{X}$ (C) 1 & $\mathrm{XC} 2$ & $\mathrm{YC}$ & $\mathrm{X}^{2} \subset 1$ & $\mathrm{X}^{2} \odot 2$ & $\mathrm{Y}^{2} \mathrm{C}$ & $\mathrm{X}(\mathrm{C} 1 . \mathrm{Y}$ & $\mathrm{X}$ (2.Y & $\mathrm{X}(\mathrm{C} 1 . \mathrm{X} 2$ \\
\hline
\end{tabular}

\section{B. Pembahasan}

Pengujian hipotesis tentang pengaruh implementasi peran guru Bimbingan Konseling (BK) dan intensitas mengikuti kegiatan OSIS (Organisasi Siswa Intra Sekolah) terhadap kedisiplinan mentaati tata tertib sekolah dilaksanakan dengan menggunakan analisis regresi dua prediktor. Hasil perhitungan diperoleh koefisien korelasi $(r y 1,2)=0,532$ setelah dikonsultasikan dengan rtabel dengan $\mathrm{N}=30$ pada taraf signifikan 5\% ditemukan besarnya rtabel = 0,312, sedangkan pada taraf signifikan $1 \%$ ditemukan besarnya rtabel sebesar $=0,403$. Ternyata besarnya harga rxy empiris > rtabel atau 0,532 >0,312 dan 0,532 >0,403. Dengan demikian ada hubungan yang signifikan antara implemenasi peran guru Bimbingan Konseling (BK) dan intensitas mengikuti kegiatan OSIS (Organisasi Siswa Intra Sekolah) terhadap kedisiplinan mentaati tata tertib sekolah pada siswa SMK Negeri 1 Polewali Kabupaten Polman.

Dari hasil perhitungan diperoleh nilai koefisien korelasi $\mathrm{Ry}^{2}$ sebesar 0,267. Hal ini menunjukkan bahwa hubungan implementasi peran guru Bimbingan Konseling (BK) dan intensitas mengikuti kegiatan OSIS (Organisasi Siswa Intra Sekolah) dengan kedisiplinan mentaati tata tertib 
sekolah sebesar $26,7 \%$, sedangkan sisanya dipengaruhi oleh variabel lain. Persamaan garis regresi yang diperoleh adalah:

$$
Y=0,280 . X 1+0,271 . X 2+34,668
$$

Dari hasil perhitungan tersebut harga Freg $=6,743$ dikonsultasikan dengan Ftabel pada taraf signifikansi $5 \%$ dengan $\mathrm{db}(2 ; 37)$ adalah sebesar 3,26 dan pada taraf signifikansi $1 \%=$ 4,38, hasilnya Fhitung $>$ Ftabel $=6,743>3,26$ atau $6,743>4,38$, sehingga hipotesis yang menyatakan ada pengaruh implementasi peran guru Bimbingan Konseling (BK) dan intensitas mengikuti kegiatan OSIS (Organisasi Siswa Intra Sekolah) terhadap kedisiplinan mentaati tata tertib sekolah dinyatakan dapat diterima.

Variabel implementasi peran guru Bimbingan Konseling (BK) memberikan sumbangan relatif (SR\%X1) sebesar 47,03\% dan sumbangan efektif (SE\%X1) sebesar 12,56\%. Variabel intensitas mengikuti kegiatan OSIS (Organisasi Siswa Intra Sekolah) memberikan sumbangan relatif (SR\%X2) sebesar 52,97\% dan sumbangan efektif (SE\%X2) sebesar 14,15\%, Sehingga nampak bahwa variabel intensitas mengikuti kegiatan OSIS (Organisasi Siswa Intra Sekolah) memiliki pengaruh yang lebih dominan terhadap kedisiplinan mentaati tata tertib sekolah dibandingkan variabel implementasi peran guru Bimbingan Konseling (BK).

\section{PENUTUP}

\section{A. Simpulan}

Berdasarkan hasil penelitian dan pembahasan maka dapat ditarik simpulan bahwa:

1. Ada hubungan yang signifikan antara implemenasi peran guru Bimbingan Konseling (BK) dan intensitas mengikuti kegiatan OSIS (Organisasi Siswa Intra Sekolah) terhadap kedisiplinan mentaati tata tertib sekolah pada siswa SMK Negeri 1 Polewali Kabupaten Polman Tahun Pelajaran 2019/2020. Hal ini dibuktikan dari hasil yang diperoleh koefisien korelasi $($ ry1,2) = 0,532 setelah dikonsultasikan dengan rtabel dengan $\mathrm{N}=30$ pada taraf signifikan $5 \%$ ditemukan besarnya rtabel $=0,312$, sedangkan pada taraf signifikan $1 \%$ ditemukan besarnya rtabel sebesar $=0,403$. Ternyata besarnya harga rxy empiris $>$ rtabel atau 0,532 >0,312 dan 0,532 >0,403.

2. Ada pengaruh implemenasi peran guru Bimbingan Konseling (BK) dan intensitas mengikuti kegiatan OSIS (Organisasi Siswa Intra Sekolah) terhadap terhadap kedisiplinan mentaati tata tertib sekolah pada siswa SMK Negeri 1 Polewali Kabupaten Polman Tahun Pelajaran 2019/2020. Hal ini dibuktikan dari harga Freg $=6,743$, dikonsultasikan dengan Ftabel pada taraf signifikansi $5 \%$ dengan db $(2 ; 37)$ adalah sebesar 3,26 dan pada tara signifikan $1 \%=$ 4,38, hasilnya Fhitung $>$ Ftabel $=6,743>3,26$ atau 6,743 $>4,38$, sehingga Ha diterima.

3. Variabel implementasi peran guru Bimbingan Konseling memberikan sumbangan relatif (SR\%X1) sebesar 47,03\% dan sumbangan efektif (SE\%X1) sebesar 12,56\%. Variabel intensitas mengikuti kegiatan OSIS memberikan sumbangan relatif (SR\%X2) sebesar 52,97\% dan sumbangan efektif (SE\%X2) sebesar 14,15\%. Sehingga intensitas mengikuti kegiatan 
OSIS memiliki pengaruh yang lebih dominan terhadap kedisiplinan mentaati tata tertib sekolah.

\section{B. Saran}

Hasil penelitian ini menunjukkan adanya pengaruh positif yang signifikan dari antara implemenasi peran guru BK dan intensitas mengikuti kegiatan OSIS terhadap kedisiplinan mentaati tata tertib sekolah. Dengan demikian jika dan intensitas mengikuti kegiatan OSIS baik didukung oleh implemenasi peran guru BK baik yang tinggi dapat dipastikan adanya peningkatan mentaati tata tertib sekolah pada siswa yang bersangkutan, begitu pula sebaliknya. Dengan demikian implemenasi peran guru BK dan intensitas mengikuti kegiatan OSIS merupakan salah satu faktor yang ikut mempengaruhi kedisiplinan mentaati tata tertib sekolah pada siswa. Oleh karena itu perlu diupayakan usaha untuk meningkatkan implemenasi OSIS yang baik. Selain itu siswa juga ditutntuk untuk meningkatkan intensitas mengikuti kegiatan OSIS guna memperbaiki tingkat ketaatan terhadap tata tertib sekolah. Hendaknya pihaksekolah memberikan suatu wadah kepada para siswa untuk dapat berkomunikasi atau berdialog dengan guru BK.

\section{DAFTAR PUSTAKA}

Arikunto, Suharsimi. Prosedur Penelitian Suatu Pendekatan Praktik. Jakarta: Rineka Cipta, 2013.

Arikunto, Suharsimi. Dasar-Dasar Evaluasi Pendidikan (Edisi Revisi). Jakarta: Bumi Aksara, 2001.

Danapriatna, Nana dan Rony Setiawan. Pengantar Statistika. Yogyakarta: Graha Ilmu, 2005.

Emzir. Metodologi Penelitian Kualitatif: Analisis Data. Jakarta: Raja Grafindo Persada, 2013.

Hurlock, E. B. Perkembangan Anak: Psikologi Perkembangan Suatu Pendekatan Sepanjang Rentang Kehidupan. Terjemahan Istiwidayanti. Jakarta: Erlangga, 1990.

Marsudi, Saring dkk. Layanan Bimbingan Konseling Di Sekolah. Surakarta: Muhammadiyah University Perss, 2004.

Moleong, Lexy J. Metode Penelitian Kualitatif. Bandung: Remaja Rosdakarya, 2013.

Mulyadi. Psikologi Pendidikan, Malang: Biro Ilmiah, FT. IAIN Sunan Ampel, 2011.

Nata, Abuddin. Metodologi Studi Islam. Cet. XXI; Jakarta: RajaGrafindo Persada, 2014.

Patoni, Achmad. Metodologi Pendidikan Agama Islam. Jakarta: Bina Ilmu, 2013.

RI. 2003. UU No. 20 tahun 2003 tentang Sistem Pendidikan Nasional. Jakarta: Sinar Grafika.

Sugiyono. Metode Penelitian Pendidikan Pendekatan Kuantitatif, Kualitatif, dan R\&D. Bandung: Penerbit Alfabeta, 2015. 